\title{
Marlim R3D: a realistic model for CSEM simulations - phase I: model building
}

Marlim R3D: um modelo realista para simulações CSEM - fase 1: construção do modelo

\author{
Bruno Rodrigues Carvalho ${ }^{1}$, Paulo Tarso Luiz Menezes ${ }^{1 *}$
}

\begin{abstract}
The marine controlled-source electromagnetic (CSEM) method provides complementary information to seismic imaging in the exploration of sedimentary basins. The CSEM is mainly used for reservoir scanning and appraisal. The CSEM interpretation workflow is heavily based on inversion and forward — modeling for hypothesis testing. Until the recent past, the effectiveness of a given workflow was achieved after the drilling results, as there wasn't any geological complex model available to serve as a benchmark. In the present paper, we describe the workflow to build up Marlim R3D, a realistic and complex geoelectric model. Marlim R3D aims to be a reference model of turbidite reservoirs of the Brazilian continental margin. Our model is based on seismic interpretation and constrained by the input of available well-log information. The workflow used is composed of seven steps: seismic and well-log dataset loading, well-tie, $V p$ cube construction, $V p$ resistivity calibration, time-depth conversion, resistivity cube construction, and quality-control check. As a result, we obtained an interpreted dataset composed by main stratigraphic horizons, pseudo-well logs, and the resistivity cubes. These elements were made freely available for research or commercial use, under the Creative Common License, at the Zenodo platform.
\end{abstract}

KEYWORDS: turbidites; CSEM; reservoir model.

\section{INTRODUCTION}

The marine controlled-source electromagnetic (CSEM) method has been accepted as a risk reduction tool in the petroleum industry. In its most typical survey configuration, it uses a horizontal electric dipole source transmitting, towed close to the marine substrate, a low-frequency $(0.01$ to $3 \mathrm{~Hz}$ ) electromagnetic signal. The receivers are sensors that, deposited on the ocean floor, can measure up to three components (X, Y, Z). More details on the method's theory can be obtained in Edwards (2005) and Constable and
RESUMO: O método eletromagnético marinho de fonte controlada (CSEM) fornece informaçôes complementares à imagem sísmica na exploração de bacias sedimentares. O CSEM é usado principalmente para escaneamento e avaliação de reservatórios. O fluxo de trabalho de interpretação CSEM é fortemente baseado em inversão e modelagem direta para testes de hipóteses. Até o passado recente, a efetividade de determinado fluxo de trabalho era alcançada somente após os resultados de perfuração. Isso em virtude de não haver nenhum modelo geológico complexo disponivel para servir de referência. No presente trabalho, descrevemos o fluxo de trabalho para construir o Marlim R3D, um modelo geoelétrico realista e complexo. Marlim R3D pretende ser um modelo de referência de reservatórios de turbiditos da margem continental brasileira. Nosso modelo baseia-se na interpretaçáo sísmica calibrada por perfis de poços disponiveis. O fluxo de trabalho empregado é composto de sete etapas: carregamento de dados sismicos e de perfis de poços, amarração sísmica-poço, construção de cubo Vp, calibração de Vp resistividade, conversão tempo-profundidade, construção de cubo de resistividade e controle de qualidade. Os elementos obtidos na construção de Marlim R3D (cubos, horizontes e perfis de resistividade em poços) são disponibilizados gratuitamente para pesquisa ou uso comercial, sob a Licença Creative Common, na plataforma Zenodo.

PALAVRAS-CHAVE: turbiditos; CSEM; modelo de reservatório.

Srnka (2007). The CSEM method had its initial development around the 1970 decade, aimed at solving academic studies in the mapping of the resistivity structure of the marine floor at great depths (Constable \& Cox 1996).

The success of these pioneering experiments enabled the expansion of CSEM usage in the 1980s and 1990s, with the unveiling of the geoelectric structure of mid-ocean ridges and submarine magmatic systems (Evans et al. 1994).

The application of CSEM in the oil industry began in the 2000s, with the pioneering survey in deep waters of Angola, and reached a market scale in the year of 2004 (Constable

1Faculdade de Geologia, Universidade do Estado do Rio de Janeiro - UERJ, Rio de Janeiro (RJ), Brazil.E-mails: Bruno.oceano@gmail.com, ptarsomenezes@pq.cnpq.br *Corresponding author

Manuscript ID: 20170088. Received on: 07/07/2017. Approved on: 10/13/2017. 
\& Srnka 2007). In 2007, the first reduction in the business activities happened. MacGregor and Tomlinson (2014) point out the lack of reliable interpretation workflows as one of the possible causes of this downfall. At that time, the effectiveness and accuracy of a given workflow were only available after post-mortem analysis of the well result.

Data generated by synthetic geoelectric models can be used to evaluate a CSEM workflow effectiveness. Most of the available models are simple physical models with a known mathematical formulation. These models are suitable for software development, but they are inefficient to represent the geological complexity of the marine substrate adequately and, hence, tend to negatively impact the workflow of real data interpretation in the hydrocarbon exploration industry (Tseng et al. 2015).

The Society of Exploration Geophysicists (SEG) recognized that issue and developed a special project for the construction of a multi-physics model, the so-called SEG Advanced Modeling (SEAM) (Fehler 2009). The SEAM Phase 1 model was constructed to represent the complex geology of the region of the allochthonous salt domains deep waters of the Gulf of Mexico (United States).

The SEAM-1 model occupies a rectangular area of approximately $1,400 \mathrm{~km} 2$. It measures $35 \mathrm{~km}$ in the eastwest direction, $40 \mathrm{~km}$ in the north-south and reaches $15 \mathrm{~km}$ in depth. Also, it is complex enough to realistically represent faults and other geological features associated with the presence of allochthonous salt bodies, such as overturned beds and overhanging salt. In the salt bodies, some turbiditic fans and braided stream channels were modeled as the hydrocarbon reservoirs in the region.

The SEAM- 1 is a multi-physics model that includes $3 \mathrm{D}$ cubes of compressional velocity $(V p)$, shear velocity $\left(V_{s}\right)$, density $(\rho)$, horizontal $(\rho h)$ and vertical $(\rho v)$ resistivities. Thus, it can be used for seismic, gravimetric and electromagnetic stand-alone or joint simulations. Since its implementation, SEAM-1 has been used by the oil companies in-house simulations, and also in the academy (Tseng et al. 2015).

In the Brazilian continental margin, turbiditic bodies make up the main post-salt plays and possible targets for CSEM surveys. Those types of reservoirs are not portrayed in the SEAM-1 models. To fill this gap, we have developed the Marlim R3D (MR3D), a realistic anisotropic geoelectric model that aims to be a standard for CSEM studies of the turbiditic reservoirs of the Brazilian continental margin (Fig, 1). Our model includes fine-scale stratigraphy and fluid-filled reservoirs, and measures $27 \mathrm{~km}$ north-south by $24 \mathrm{~km}$ east-west by $6 \mathrm{~km}$ depth.

MR3D is based on previous 3D seismic interpretation (Nascimento et al. 2014) and constrained by public well$\log$ data and regional geological information.
In the present paper, we concentrate on the description of the geoelectric model building at a seven sequential steps workflow: seismic and well-log database, well-tie, $V p$ cube, $V p$ resistivity calibration, time-depth conversion, resistivity cube output, and quality-control check.

The interpreted dataset including 3D cubes of $(\rho h)$ and $(\rho v)$ resistivities in SEG-Y format, composed by main stratigraphic horizons, pseudo- well-ogs, are freely downloadable, for research or commercial use, under the Creative Common License, on the Zenodo (Carvalho \& Menezes, 2017).

\section{CAMPOS BASIN STRATIGRAPHIC SETTING}

The sedimentary section of the Campos Basin can be grouped into three mega-sequences associated to the following tectonic development stages: rift, transitional and drift (Fig. 2).

The Barremian lacustrine sediments of Lagoa Feia Formation overlie the Hauterivian Cabiu'nas basalts (120$130 \mathrm{Ma}$ ); these basalts represent the economic basement of Campos Basin. The Lagoa Feia sediments are recognized as the most valuable source rocks in the Campos Basin.

The Aptian sequence contains, from base to top: conglomerates, carbonates and evaporitic rocks deposited during a period of tectonic quiescence. This transitional stage expresses the beginning of the drift phase in which the sediments are correlated with the first sea-water inflows through the Walvis Ridge (Leyden et al. 1976).

The drift stage commences with a marine mega-sequence characterized by the Albian/Cenomanian shallow-water calcarenites and calcilutites of Maca'e Formation. The marine Upper Cretaceous to Paleogene deep-water clastic section (Carapebus Formation) is composed of shale, marls and sandstone turbidites, deposited in a period of general tectonic quiescence and of continued subsidence. The turbidite systems constitute the most valuable petroleum reservoirs in the Campos Basin (Bruhn et al. 2003). Progradational siliciclastic sequences characterize the Neogene section. In the deep-water of the Campos Basin, the deposition of this mega-sequence was greatly conditioned by salt tectonics (Mohriak et al. 1996).

\section{MODEL BUILDING WORKFLOW}

There are several options for building a 3D geoelectric model. Park et al. (2015), for example, interpolate and extrapolate the resistivities of wells respecting the stratigraphy along the studied area. However, for the application 
of such technique, it is necessary to have a large number of wells in hand, and that these wells should have information of the entire stratigraphic column to be extrapolated. A relative weakness of that approach is the fact that lateral facies variation between the wells cannot be adequately represented through the simple interpolation.

A second widely used alternative is the construction of the resistivity cube based on a velocity-porosity-resistivity petrophysical models available in the literature (Hashin \& Shtrikman 1962; Hermance 1979; Werthmu“ller et al. 2013).

In the present work, we estimate the direct relationship between velocity and resistivity, then we use this relation to interpolate and extrapolate the resistivities accompanying previous stratigraphic knowledge throughout the study area. To this end, we defined a workflow consisting of seven main stages:

- Seismic and well-log database;

- Seismic-well tie;

- Vp cube;

- $V p \times$ resistivity relationship;

- Time to depth conversion;

Resistivity cubes;

Quality control.

\section{Seismic and well-log database}

In late 1996, early 1997, Geco-Prakla collected for Petrobras the 3D seismic data interpreted in this study. The survey area spanned over $720 \mathrm{~km}$ (Johann et al., 2009). The survey acquisition parameters are presented in Table 1 .

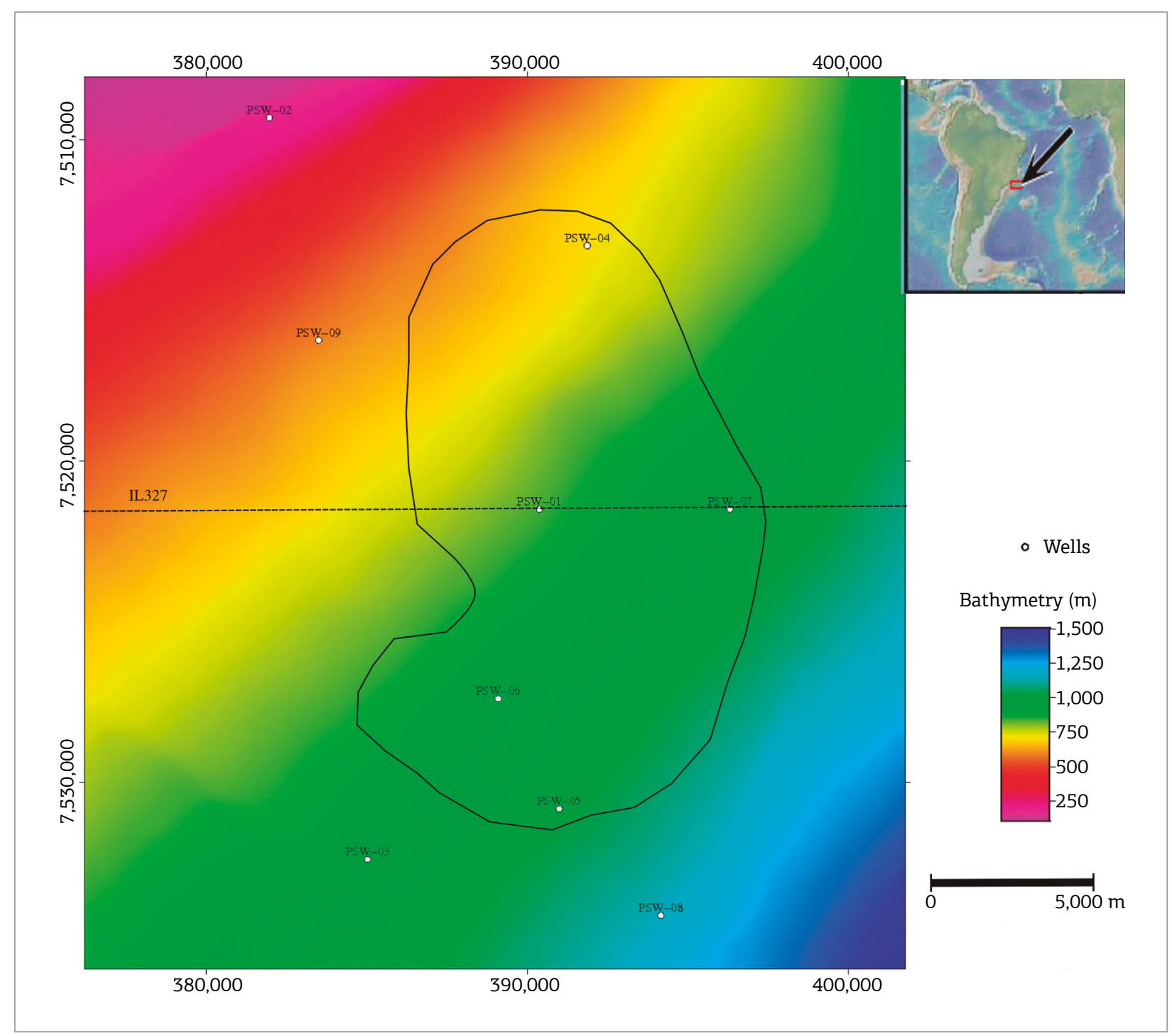

Figure 1. Location map of the seismic dataset at Marlim field. Coordinates are in UTM, zone 39S. Marlim reservoir outline is shown in the black line. The dashed lines corresponds to the interpreted inline 327. PSW-01 to PSW-09 are the available wells. 
The Brazilian Petroleum Agency (ANP) made available the public seismic dataset by providing a post-stack time-migrated 3D seismic amplitude cube (Tab. 2), as well as check shots, stratigraphic markers, and composite well logs - density $(\rho)$, sonic (DT), porosity $(\varphi)$, gamma ray $(\mathrm{GR})$, and horizontal resistivity $(\rho h)$ of nine wells in the study area (Fig. 1).

We have built an integrated database in an open-source seismic platform and loaded the wells' information (stratigraphic markers and well-log curves), the dip-steering (DS) filtered seismic data and the main stratigraphic horizons interpreted by Nascimento et al. (2014). Those authors have shown that the DS filtered data, in which random spurious noises were attenuated, highlight the main reflections related to stratigraphy and therefore they would be more amenable to interpretation.

The high quality of the filtered seismic data and the six main stratigraphic horizons from the seafloor to the bottom of the salt, according to theinterpretation, are illustrated in Figure 3.

\section{Well-log editing}

We have applied an editing and preconditioning filtering step for the well data. All log curves were cascade filtered with a spike removal filter followed by a low-pass moving average filter. That step is necessary to remove undesirable

Table 1. Seismic acquisition parameters.

\begin{tabular}{l|c}
\hline & 1997 Acquisition \\
\hline Area (km2) & 720 \\
\hline Number of cables & 0 \\
\hline Spreads (offset, m) & 288 \\
\hline Channels/cable & 25 \\
\hline Shot point interval (m) & 12.5 \\
\hline Receiver interval (m) & 50 \\
\hline Cable interval (m) & 1 \\
\hline Sample rate (ms) & $12.5 \times 25$ \\
\hline Bin size (m) & 9 \\
\hline Cable depth (m) & 123 \\
\hline Azimuth (degrees) & 72 \\
\hline Nominal fold & 230,400 \\
\hline Traces/km² &
\end{tabular}

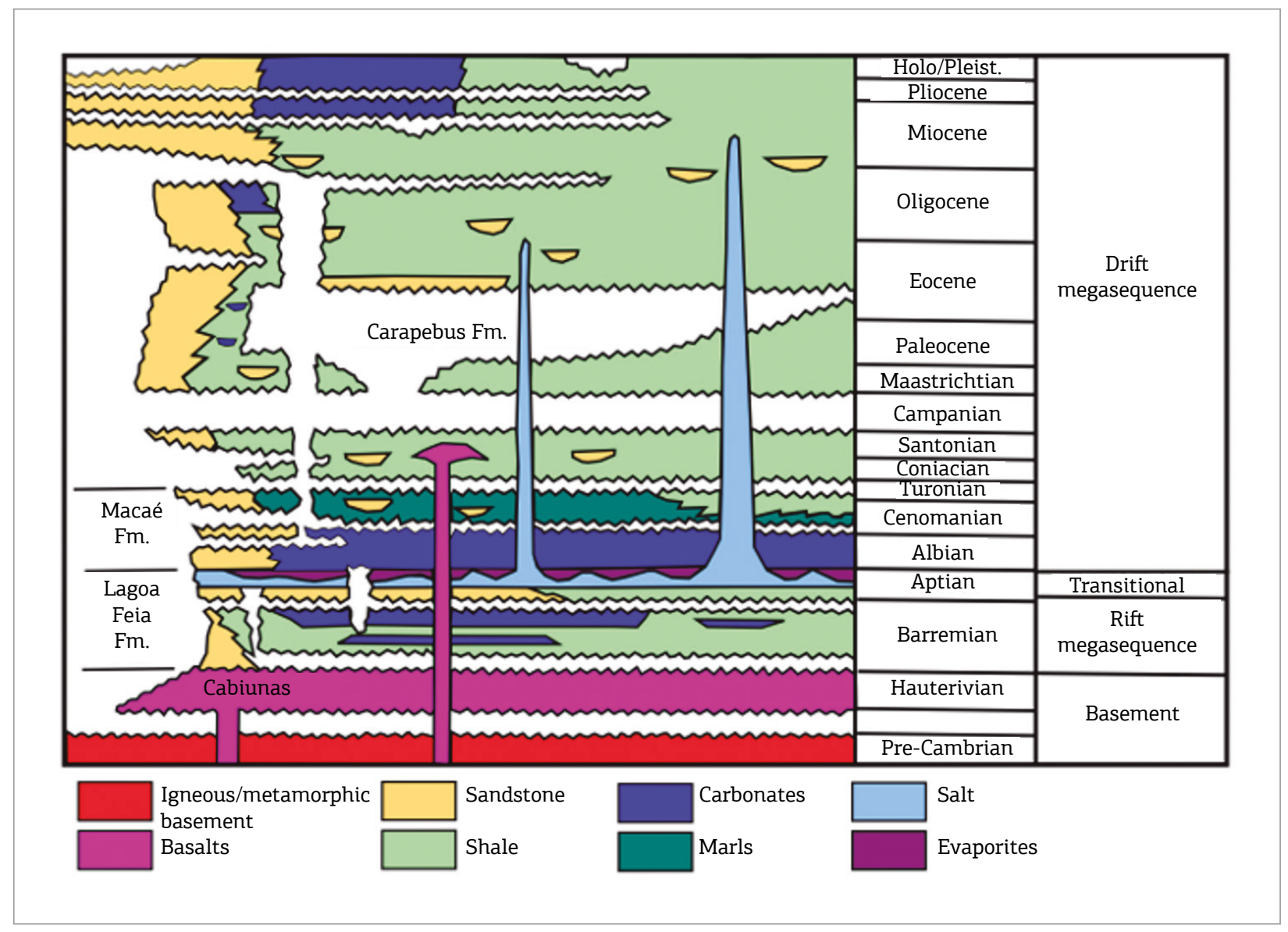

Figure 2. Simplified stratigraphic chart of the Campos Basin, modified from Guardado et al. (2000). 
noise, and to bring the log information closer to the seismic resolution.

We calculated the $V p$ logs from the sonic curves by using the $V p=1 / D T$ relation. Sequentially, we computed the acoustic impedance (AI) logs from $(V p)$ and density logs.

\section{Seismic-well tie}

Well ties are an essential part of the interpreter's job. The major goal is to correlate the stratigraphic markers described in the wells with the seismic reflections aiming

Table 2. 3D cube parameters.

\begin{tabular}{l|c}
\hline Parameter & Quantity \\
\hline Inlines & 429 \\
\hline Inlines direction & east-west \\
\hline Inlines spacing & $25 \mathrm{~m}$ \\
\hline Crosslines & 1,115 \\
\hline Crosslines direction & north-south \\
\hline Crossline spacing & 12,5 m \\
\hline Time window & $60-4,996$ miliseconds \\
\hline Sampling rate & 4 miliseconds \\
\hline
\end{tabular}

to provide a correct identification of the horizons to pick. Getting a well tie is quite simple: synthetic seismograms calculated from well-log curves are matched to the actual seismic traces, and the features of the well in the depth domain are correlated to the seismic data in the time domain.

Synthetic seismograms are obtained from the convolution of the reflectivity series in time with a wavelet representing the seismic source. Frequently interpreters extract that wavelet from the seismic data (White \& Simm 2003).

The acoustic impedance (AI) and the reflectivity $(R p)$ for any two given media are defined, respectively, by Equations 1 and 2.

$A I=V p \times \rho$,

$R p=\frac{A l_{2}-A l_{1}}{A l_{1}+A l_{2}}$

In which:

AI1 and AI2 correspond, respectively, to the impedance of the first and second layers.

In the present study, we performed the seismic-well tie process by employing the following steps:

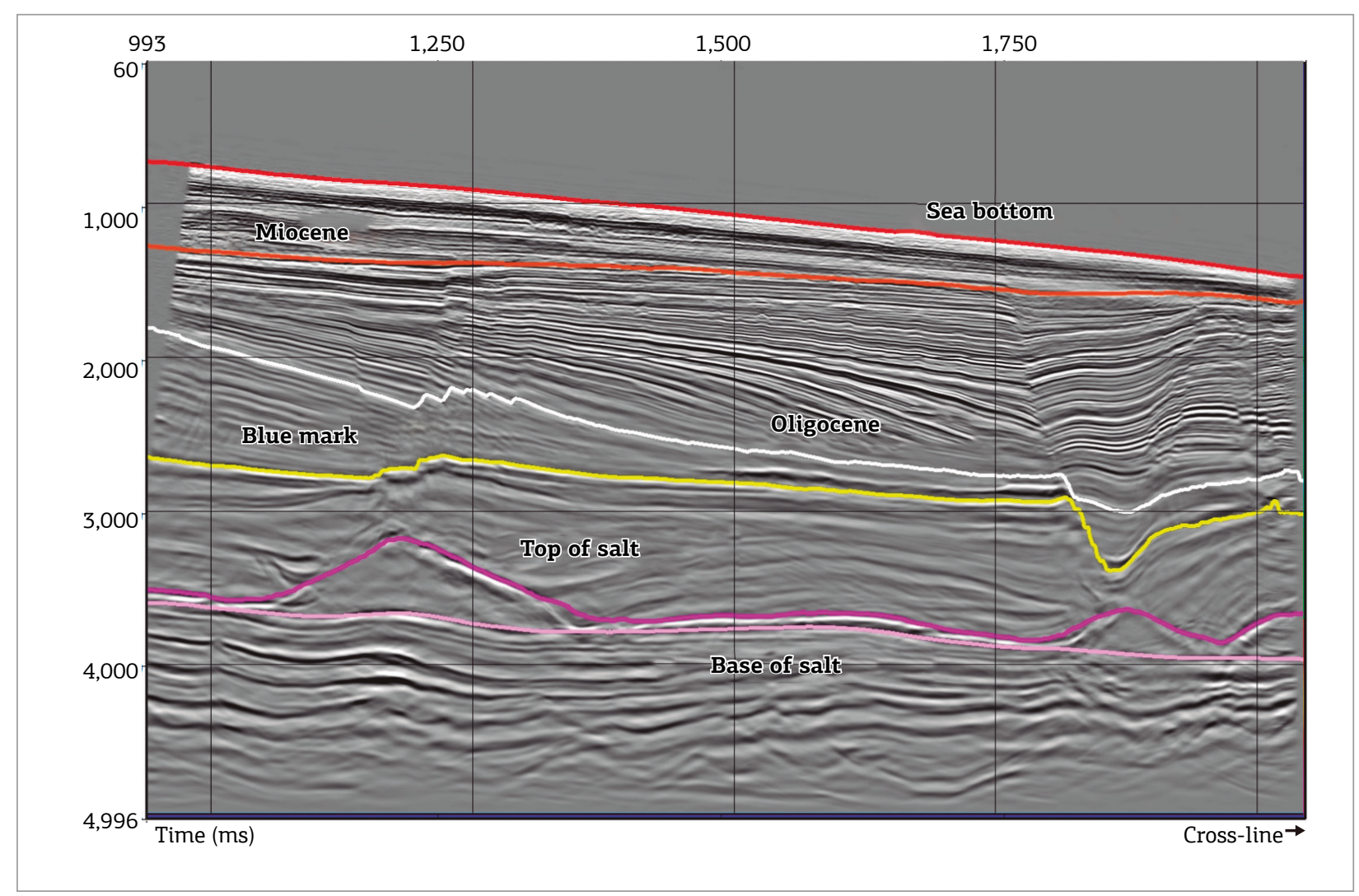

Figure 3. Inline 327 with the main interpreted seismic horizons. 
- The seismic traces are bounded by a time window (taper length) and then extracted;

- Autocorrelation, in the time domain, of the seismic traces within the window defined in the previous step;

Employ the direct Fourier transform to obtain the autocorrelation's frequency spectrum;

- Calculate the square root of the frequency spectrum's module and then subtract the zero frequency component;

- Apply the inverse Fourier transform; the real part of the inverse of the Fourier transform corresponds to extracted zero phase wavelet in time.

The final step of the seismic-well tie is given by the association between the synthetic seismogram and the seismic data in the vicinity of the well, resulting in a correlation panel for each well, as shown in Figure 4.

\section{Vp cube}

The $V p$ cube was built from the interpolation of the $V p$ curves along the studied area. At depths beyond the wells' information, we employed $V p$ estimates available in the literature.

The interpolation follows the stratigraphic knowledge given by the interpreted horizons along a Horizon Cube by Groot et al. (2010), which consists of a dense 3D set of stratigraphic surfaces associated with a given geological age. Consequently, hundreds of chrono-stratigraphically correlated horizons, with similar strike and dip, are generated (Qayyum \& Smith 2014).

The Horizon Cube was created using six stratigraphic intervals, bounded by the main horizons mapped by Nascimento et al. (2014): Seabed-Miocene, MioceneOligocene, Oligocene-Blue Mark, Blue Mark-Top of Salt, Top of Salt-Base of Salt, and Base of Salt-End of Model. The latter one, a 4,976 m time-slice horizon, aiming to represent the base of the model.

The Horizon Cube is shown in Figure 5A, and the $V p$ cube is shown in Figure 5B. We used a single velocity of $4,500 \mathrm{~m} / \mathrm{s}$ to the salt sequence (Schön 2015), and a regional velocity trend published by Bulhóes et al. (2015) to the sediments of the Lagoa Feia Group up to the basement rocks.

\section{$\mathrm{Vp} \times$ resistivity relationship}

\section{Background resistivity}

Relations between elastic and electrical rock properties have been investigated both theoretically (e.g., Carcione et al. 2007) and empirically (e.g., Faust 1953; Gomez et al. 2010). Primary applications of such cross-property relationship include filling in data gaps when one property is more readily available than the other. Advanced uses of such relationship include the input of a priori information to reduce ambiguity in the inversion process (Mukerji et al. 2009; Werthmu“ller et al. 2013).

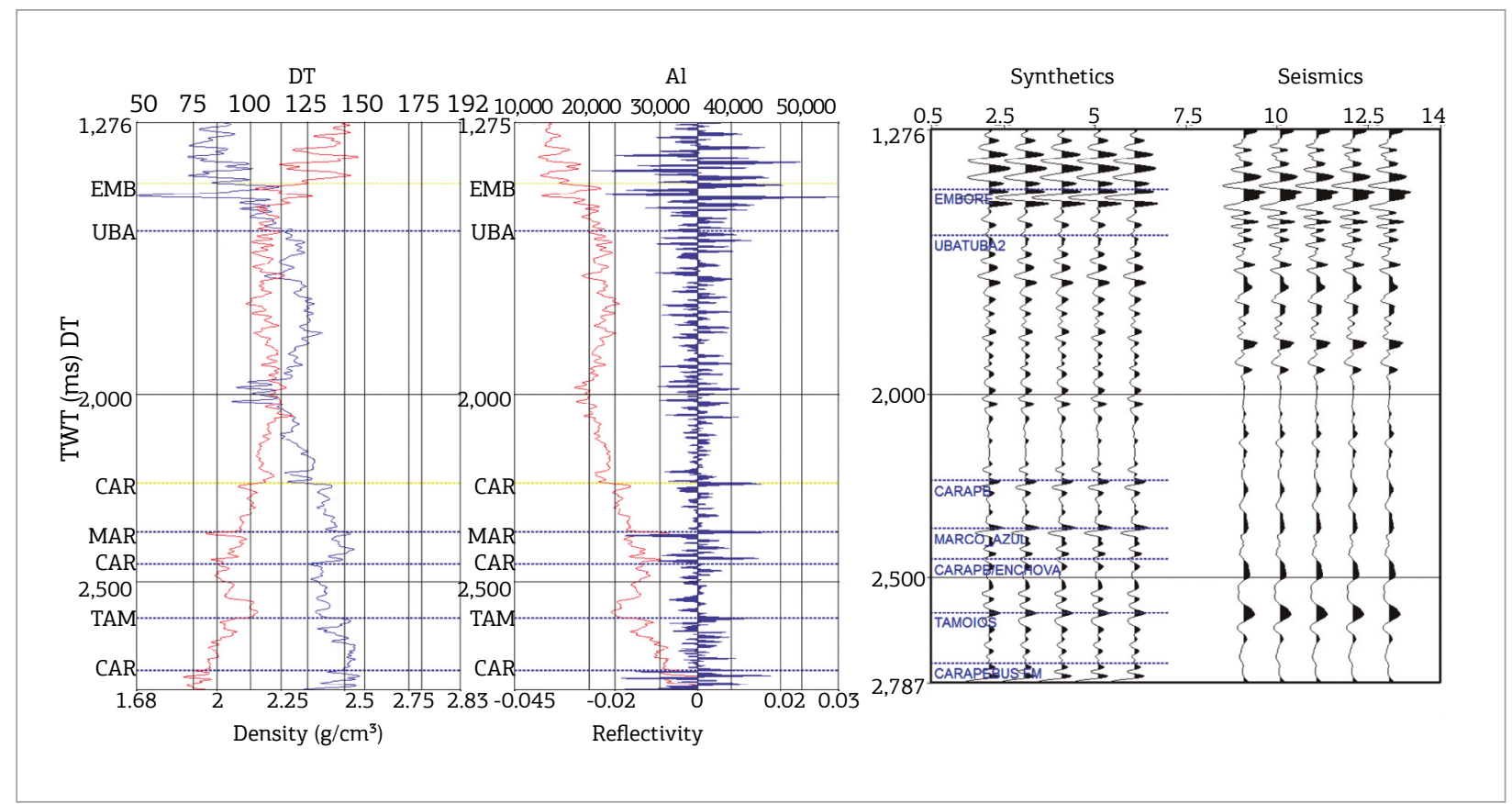

Figure 4. Well-tie correlation panel. Left panel) sonic (red curve) and density (blue curve) logs in the 1,276 to 2,797 ms time interval; central panel) acoustic impedance (AI) log (red curve) and reflectivity (blue curve). Right panel comparison between the synthetic and acquired seismic. EMB (Emboré), UBA (Ubatuba), CAR (Carapeba), MAR (Marco Azul), and TAM (Tamoios) are stratigraphic markers. 
Faust (1953) has shown that both resistivity and velocity behave similarly with increasing depth. To investigate that subject in the studied area, we plotted in Figure 6 the measured horizontal resistivity $(\rho h)$ and $V p$ at all available wells against depth. As our goal was to define the background (or regional) resistivity, we did not take into

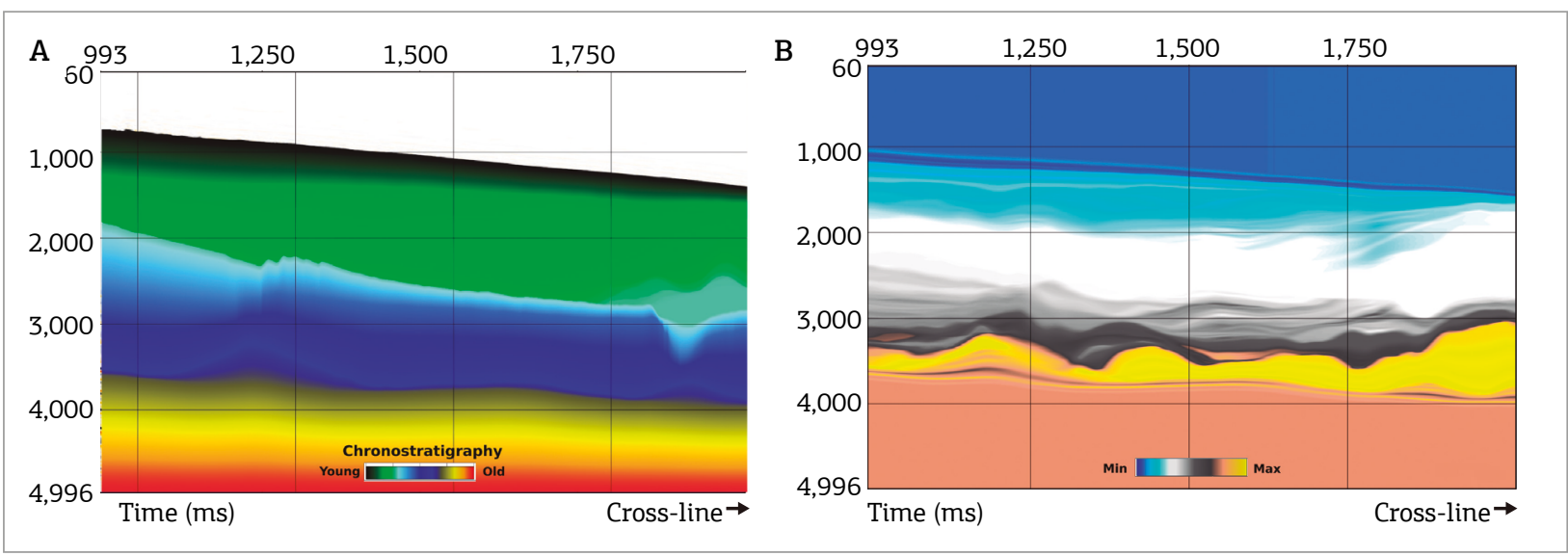

Figure 5. (A) Inline 327 extracted from the Horizon Cube, a stack of chronostratigraphic 3D horizons extracted at inline 317; (B) Vp interpolated along the inline 327 from the Horizon Cube shown in Figure 5A.

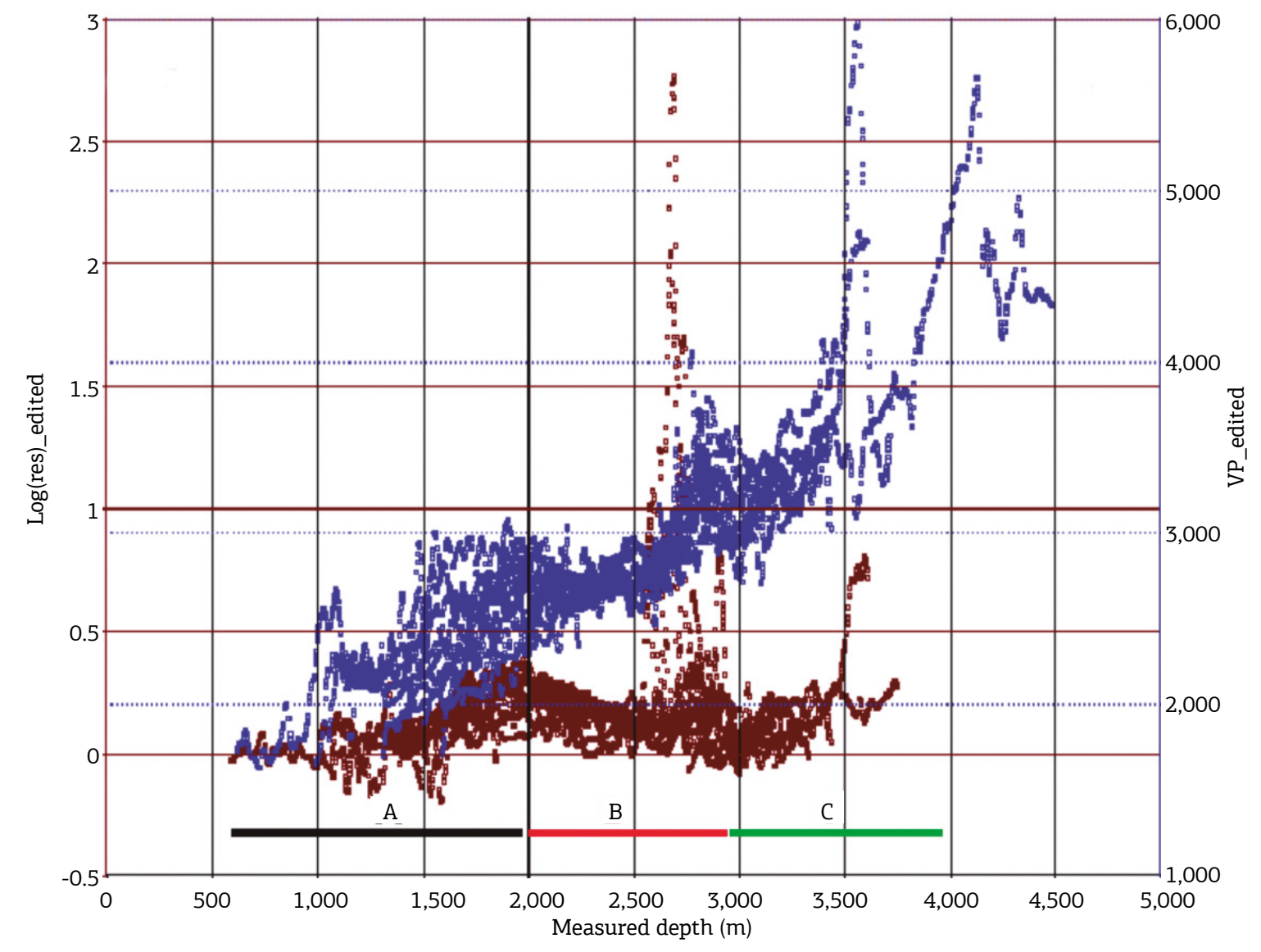

Figure 6. Vp (blue) and resistivity (brown) logs of all nine wells plotted versus depth. A, B, and C are depth intervals herein interpreted. 
account the high resistivity values associated with the reservoir (average of $70 \mathrm{o} \mathrm{hm.m)}$.

In Figure 6 we have classified three distinct zones: 600-2,000 m (zone A), 2,000-2,900 m (zone B), and depths greater than $2,900 \mathrm{~m}$ (zone C). Then, we calculated the relationship between $\log (\rho h)$ and $V p$ by crossploting these two quantities at each identified A, $\mathrm{B}$, and $\mathrm{C}$ depth zones. The crossplots of the respective zones are shown in Figures 7A, 7B and 7C. Hence, by least-squares fitting, we obtained three linear equations (Eqs. 3, 4 and 5) relating the background horizontal resistivity and velocity.

$\rho h 600-2,000 m=-0.263+0.000166 V p$,

$\rho h 2,000-2,900 m=-0.0683+2,798.10-5 V p$,

$\rho h>2,900=-0.09+0.00037 V p$

In which $\rho h$ 600-2,000 $m, \rho h$ 2,000-2,900 $m$, and $\rho h$ 2,900-end represent, respectively, the horizontal resistivity in the range of 1,000-2,000 meters, 2,000-2,900 meters and depths greater than 2,900 meters. At depth zone C, the exception is the salt sequence (defined by top and base of salt horizons), where we assigned the single value of 1,000 ohm.m (Zerilli et al. 2016).

\section{Anomalous resistivity}

The high resistivities associated with the oil-prone Marlim turbidite sands match the anomalous reservoir values embedded in the low-resistivity regional background of the non-reservoir facies in depth zone b (Eq. 4).

Consequently, it is necessary to distinguish between the reservoir and the non-reservoir facies, and then associate the anomalous resistivity value only to the reservoir facies. To that end, we follow the interpretation of Nascimento et al. (2014), that described the reservoir facies with the acoustic impedance lower-equal than $5,700 \mathrm{~m} / \mathrm{s} . \mathrm{g} / \mathrm{cm}^{3}$ and porosity in the $0.26-0.32 \%$ range.

To that end, we created an algorithm (Algorithm 1) to identify and assign the Marlim reservoir facies resistivity and distinguish it from the background values. The input are the $V p$, porosity and AI cubes.

Both anomalous and background relationships was used to convert the $V p$ cube into resistivity cube.

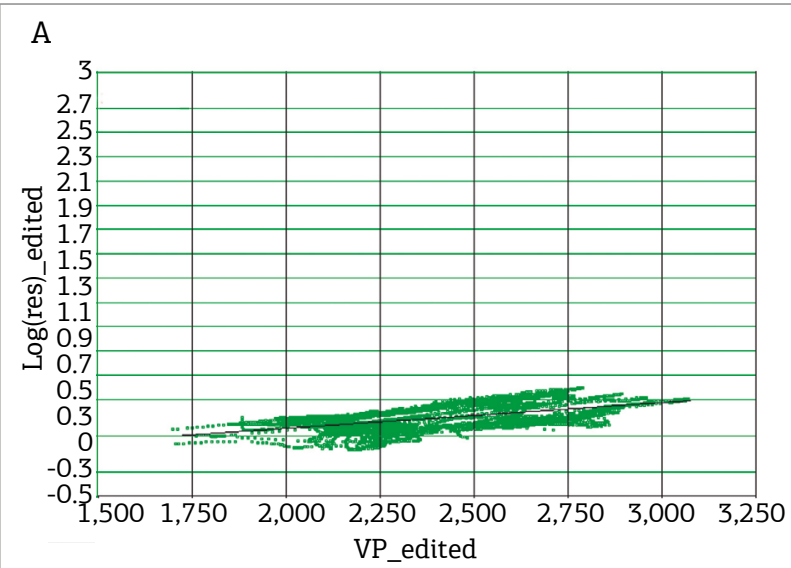

B

C
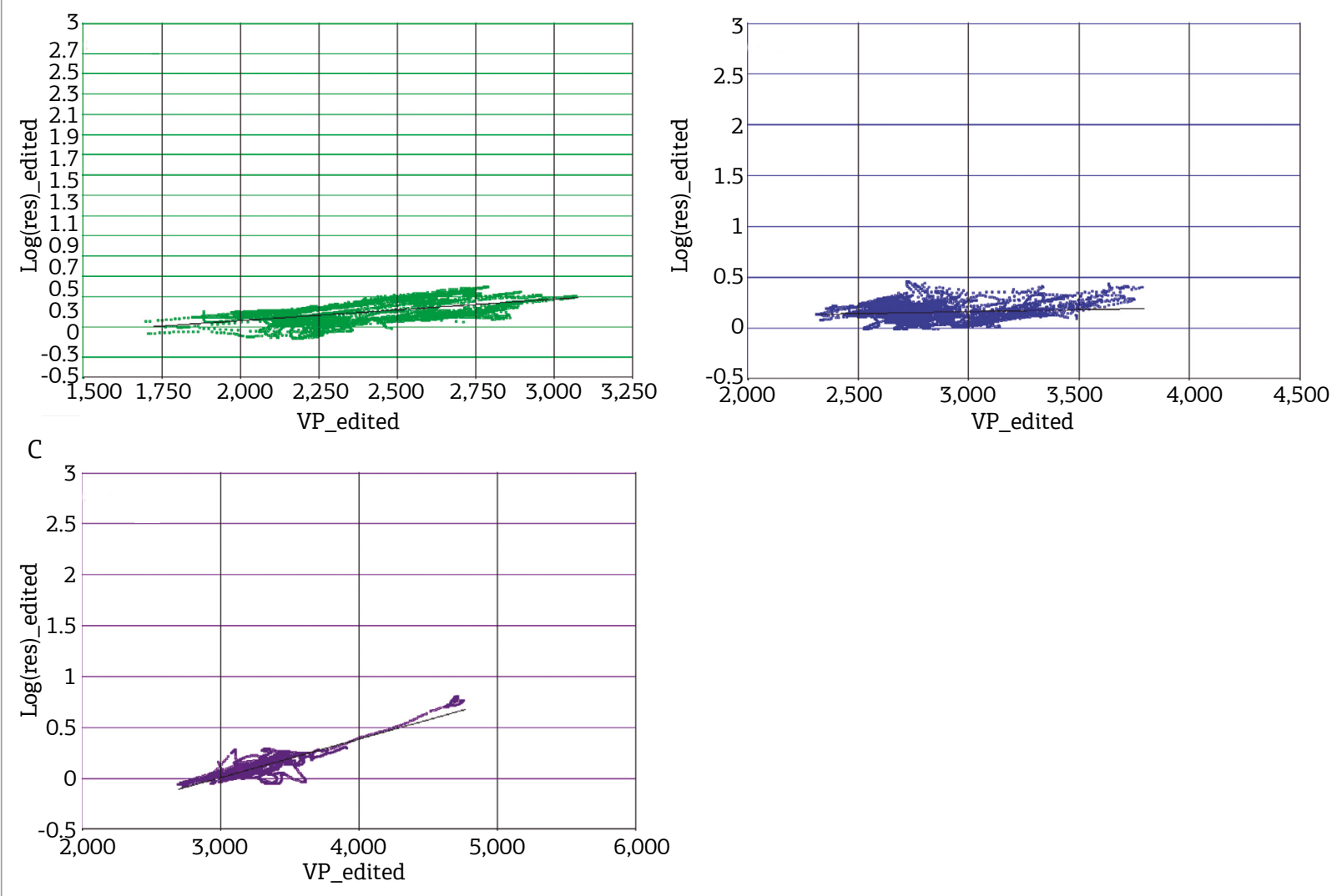

Figure 7. Relations between resistivity and $V p$ for all nine wells at three distinct depth intervals (Figure 6): (A) depth interval A; (B) depth interval B; (C) depth interval C. 


\section{Time to depth conversion}

There are several methods for the time-depth (T-D) conversion. However, one can distinguish two main categories (Etris et al. 2001):

Direct conversion;

Velocity modeling.

We have followed the second option, by building an interval velocity model based on the well-log ties curves. Those were smoothed and interpolated along the studied area using the Horizon Cube. For the salt and subsalt sequences, we have applied, respectively, a constant $4,550 \mathrm{~m} / \mathrm{s}$ interval velocity, and a velocity trend based on the studies of Bulhóes et al. (2015).

The T-D conversion was made following two main steps, First of all, we did it only at seismic sections crossing the wells as a QC. Depth converted horizons were checked against the position of their correspondent stratigraphic marker at the wells. The final interval velocity model is shown in Figure 8.

In the second step, we used the 3D interval velocity model to convert to depth all the available property cubes: $\rho h, \rho v, V p$, porosity and acoustic impedance and also the main stratigraphic horizons.

\section{RESISTIVITY CUBES}

To compute the $\rho h$ cube from the $V p$ cube, we developed a second algorithm (Algorithm 2). The input is the

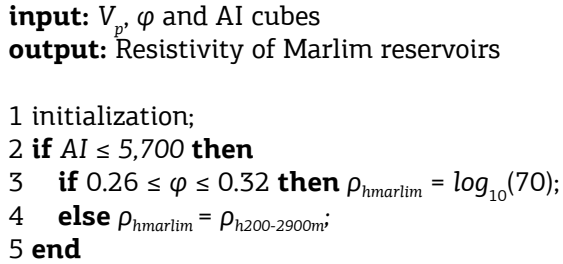

Algorithm 1. Marlim reservoir resistivities.

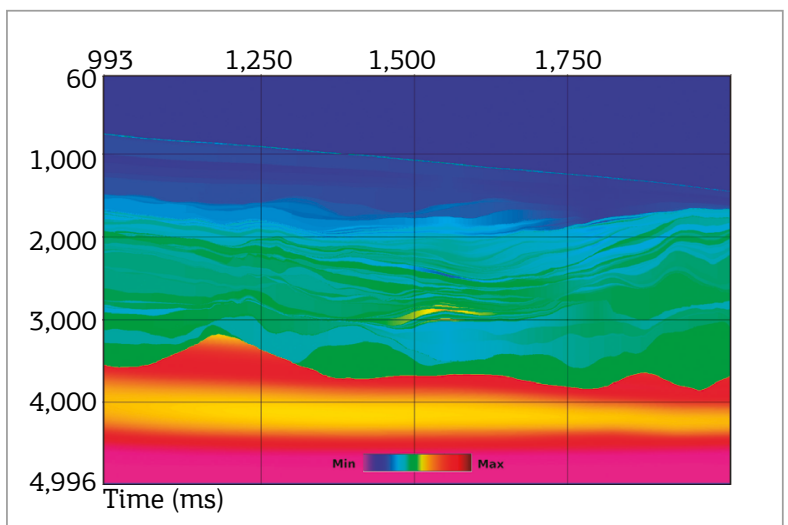

Figure 8. Interval Velocity, used in the time to depth conversion, extracted at Inline 327.
$V p$, porosity and acoustic impedance cubes, but also some of the stratigraphic horizons.

Algorithm 2 implements both the background resistivities and incorporate algorithm 1 to distinguish between the reservoir and non-reservoir facies. We settled a stratigraphic window between the Top of Oligocene and BlueMark horizons (depth interval between 2,000-2,900m). BlueMark, a maximum flood surface of the Eo-Oligocene, is considered the base of the turbiditic reservoirs (Gamboa et al. 1986).

We used an anisotropic ratio $(\rho v / \rho h)=2.5$ to calculate Marlim-R3D vertical resistivity cube from the horizontal resistivity cube (Park et al. 2015). That ratio was applied to the whole sedimentary section, except for the salt bodies that were handled as isotropic layers.

\section{QUALITY CONTROL}

To perform the quality control (QC) of the converted resistivity cube, we crossplot the recovered values against the measured resistivity in wells. Then we find a linear relationship by least-squares fitting, which fits both data to a specific correlation coefficient. That coefficient stands between 0 and 1 ( 0 to $100 \%)$.

For the sake of brevity, we show in Figure 9 the results for only one well: PS-W-01, which correlation coefficient is 0.95 , i.e., a $95 \%$ agreement between the modeled and measured resistivity was obtained.

As can be seen in Figure 9, the resistive turbidite sandstones that form the reservoir of the Marlim Field are properly outlined at depth, with top and base coinciding with the well information.

Figure 10 shows the vertical resistivity extracted along Top of Marlim horizon slice. The Marlim reservoir facies emerges as a high resistivity body embedded in a low-resistivity

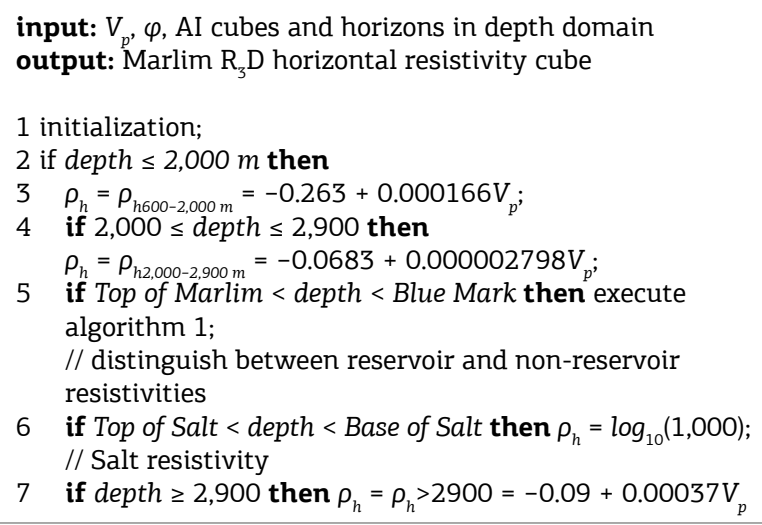

Algorithm 2. Calculation of the horizontal resistivity in the depth domain. Topof Marlim, Blue Mark, Top of Salt and Base of Salt are stratigraphic horizons. 

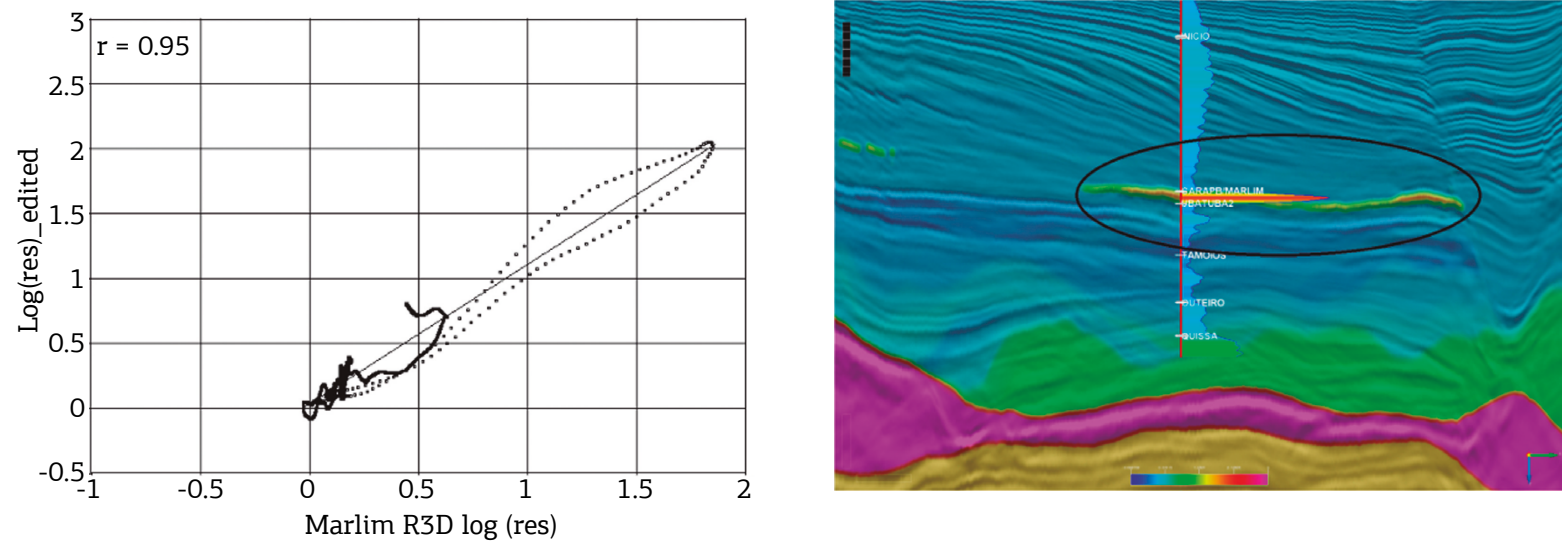

Figure 9. Right panel: crossplot between recovered $\rho$ h versus measured resistivity (ILD log) at PS-W-01 well. Left panel: comparison between the recovered $\rho$ h along an arbitrary section and the measured resistivity log at PS-W-01 well.

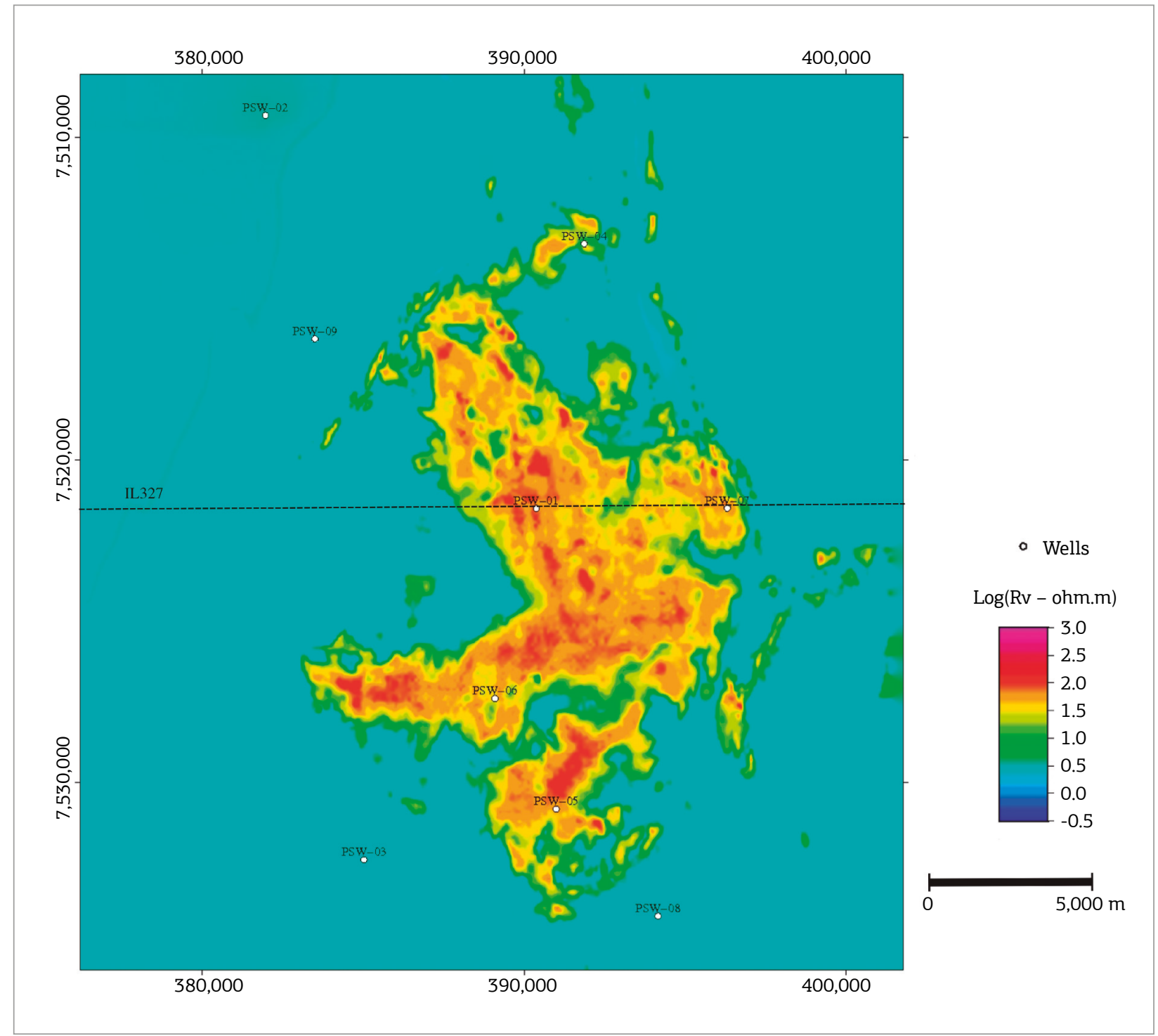

Figure 10. Map of the vertical resistivity distribution along a horizon at the top of Marlim reservoir. PSW-01 to PSW-09 are the available wells. The Marlim turbidites (clean sandstones) are clearly highlighted as highresistivity bodies. Shale and shaly sand (non-reservoir) facies show lower ressitivity values. 
background. Rather than a single resistivity body, as commonly pictured in most of the available resistivity models, including the SEAM-Phase I model, Marlim R3D exhibits a complex resistivity pattern. That is in agreement with the expected geological complexity of the turbidite bodies.

\section{CONCLUSIONS}

We present Marlim R3D, a realistic geoelectric model for CSEM simulations. The Marlim R3D aims to be a benchmark model for studies of turbiditic reservoirs.

The Marlim R3D model comprises a data set consisting of $\rho h$ and $\rho v$ cubes in SEG-Y format, the six stratigraphic horizons, and $V p, \rho h$ and $\rho v$, well-logs extracted from Marlim R3D in the position of nine wells. These well-logs aim to serve as a quality control of modeling and inversions studies using Marlim R3D.

These cubes are being made freely available to the general public on the Zenodo.

The cube is rendered in SGY format with data distributed along $75 \times 25 \times 5 \mathrm{~m}$ cells. We are currently developing a detailed 3D CSEM finite-difference forward study to generate an official CSEM dataset for Marlim R3D. The full dataset will be soon delivered to general public at the Zenodo platform.

Although primarily conceived to be a CSEM reference model, Marlim R3D can also be used to simulate responses to any electromagnetic method such as marine magnetotellurics, surface-to-borehole EM, or even crosswell-EM studies.

\section{ACKNOWLEGMENTS}

We thank dGB Earth Sciences for making freely available the open-source seismic interpretation software OpendTect. We acknowledge Laboratório de Geofísica Exploratória at Universidade do Estado do Rio de Janeiro (LAGEX/UERJ) for making available its computational park. P. Menezes thanks the support provided by research grant from the Brazilian National Council for Scientific and Technological Development $(\mathrm{CNPq})$. Data set made available under the support of the CNPq Project coordinated by A. Evsukoff. We also thank the additional support by CNPq project no. 470742/2011-9.

\section{REFERENCES}

Bruhn C.H.L., Gomes J.A.T., Del Lucchese Jr.C., Johann P.R.S. 2003. Campos basin: Reservoir characterization and management-historical overview and future challenges. In: Offshore Technology Conference. Rio de Janeiro, p. 14

Bulhões F.C., Formento C.D.R., Lyrio J.C.O., Amorim G.A., Ferreira G.D., Pereira E.S., Castro R.F. 2015. Geostatistical 3d density modeling: Integrating seismic velocity and well logs. In: $14^{\text {th }}$ International Congress of the Brazilian Geophysical Society \& EXPOGEF. Rio de Janeiro, Brazilian Geophysical Society, p. 272-277.

Carcione J.M., Ursin B., Nordskag J.I. 2007. Cross-property relations be- tween electrical conductivity and the seismic velocity of rocks. Geophysics, 72(5):E193-E204.

Carvalho B.R. \& Menezes P.T.L. 2017. Marlim R3D - A Realistic Model For Mcsem Simulation. Zenodo, https://doi.org/10.5281/ zenodo.400233.

Constable S. \& Cox C.S. 1996. Marine controlled-source electromagnetic sounding: 2. the Pegasus experiment. Journal of Geophysical Research, 101(B3):5519-5530.

Constable S. \& Srnka L.J. 2007. An introduction to marine controlledsource electromagnetic methods for hydrocarbon exploration. Geophysics, 72(2):WA3-WA12.

Edwards N. 2005. Marine controlled source electromagnetics: Principles, methodologies, future commercial applications. Surveys in Geophysics, 26(6):675-700.

Etris E.L., Crabtree N.J., Dewar J. 2001. True depth con- version: More than a pretty picture. Canadian Society of Exploration Geophysicists, 26(9):11-22
Evans R.L., Sinha M.C., Constable S.C., Unsworth M.J. 1994. On the electrical nature of the axial melt zone at $13^{\circ} \mathrm{N}$ on the East Pacific Rise. Journal of Geophysical Research, 99(B1):577-588.

Faust L.Y. 1953. A velocity function including lithologic variation. Geophysics, 18(2):271-288.

Fehler M. 2009. SEAM phase I progress report: "classic" data sets. The Leading Edge, 28(10):1178-1181.

Gamboa L., Esteves F., Shimabukuro S., Carminatti M., Peres W.

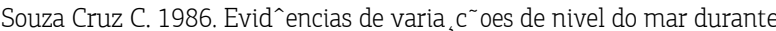
o oligoceno e suas implica, ${ }_{5}{ }^{\sim}$ oes faciol'ogicas. In: SBG, Congresso Brasileiro de Geologia, p. 8-22

Gomez C.T., Dvorkin J., Vanorio T. 2010. Laboratory measurements of porosity, permeability, resistivity, and velocity on Fontainebleau sandstones. Geophysics, 75(6):E191-E204

Groot P., Huck A., Bruin G., Hemstra N., Bedford J. 2010. The horizon cube: A step change in seismic interpretation! The Leading Edge, 29(9):1048-1055.

Guardado L.R., Spadini A.R., Brand ao J.S.L., Mello M.R. 2000. Petroleum system of the Campos Basin, Brazil. American As- sociation of Petroleum Geologists, 317-324.

Hashin Z. \& Shtrikman S. 1962. A variational approach to the theory of the effective magnetic permeability of multiphase materials. Journal of Applied Physics, 33:3125-3131.

Hermance J.F. 1979. The electrical conductivity of materials containing partial melt: A simple model from Archie's law. Geophysical Research Letters, 6(7):613-616. 
Johann P., Sansonowski R., Oliveira R., Bampi D. 2009. 4D seismic in a heavyoil, turbidite reservoir offshore Brazil. The Leading Edge, 28(6):718-729.

Leyden R., Asmus H., Zembruscki S., Bryan G. 1976. South Atlantic diapiric structures. AAPG Bulletin, 60(2):196-212.

MacGregor L. \& Tomlinson J. 2014. Marine controlled-source electromagnetic methods in the hydrocarbon industry: A tutorial on method and practice. Interpretation, 2(3):SH13-SH32.

Mohriak W.U., Macedo J.M., Castellani R.T. 1996. Salt tectonics and structural styles in the deep-water province of the Cabo Frio region, Rio de Janeiro, Brazil. The American Association of Petroleum Geologists Memoir .

Mukerji T., Mavko G., Gomez C. 2009. Cross-property rock physics relations for estimating low-frequency seismic impedance trends from electromagnetic resistivity data. The Leading Edge, 28(1):94-97.

Nascimento T.M., Menezes P.T.L., Braga I.L. 2014. High-resolution acoustic impedance inversion to characterize turbidites at Marlim Field, Campos Basin, Brazil. Interpretation, 2(3):T143-T153.

Park J., Viken I., Menezes P.T.L., Filho C.E.B.L., Dabbadia M.R.A. 2015. Feasibility of borehole-surface EM for $\mathrm{CO} 2$ injection monitoring with a synthetic-field case. In: SEG Technical Program Expanded Abstracts. Society of Exploration Geophysicists, p. 1033-1038.
Qayyum F. \& Smith D. 2014. Integrated sequence stratigraphy using trend logs and densely mapped seismic data. First Break, 32(12):75-84.

Schön J.H. 2015. Physical properties of rocks: Fundamentals and principles of petrophysics. volume 65, Elsevier, 497p.

Tseng H.W., Stalnaker J., MacGregor L.M., Ackermann R.V. 2015. Multi-dimensional analyses of the SEAM controlled source electromagnetic data - the story of a blind test of interpretation workflows. Geophysical Prospecting, 63(6): 1383-1402.

Werthmu“ller D., Ziolkowski A., Wright D. 2013. Background resistivity model from seismic velocities. Geophysics, 78(4):E213-E223.

White R.E. \& Simm R. 2003. Tutorial: Good practice in well ties. First Break, 21.

Zerilli A., Buonora M.P., Menezes P.T.L., Labruzzo T., Mar ${ }_{3}$ cal A.J., Crepaldi J.L.S. 2016. Broadband marine controlled-source electromagnetic for subsalt and around salt exploration. Interpretation, 4(4):T521-T531.

Available at www.sbgeo.org.br 